\title{
Effect of In-situ Rainwater Conservations and Sowing Date on Barley Yield and Weed Infestation: A Case study at Maychew and Mekelle, Northern Ethiopia
}

\author{
Abrham Tezera Gessesse ${ }^{1}$, Araya Alemie Berhe ${ }^{2}$ \\ ${ }^{1}$ Agriculture, Soil and Water Conservation, Debre Birhan Agricultural Research Center, ETHIOPIA \\ ${ }^{2}$ Dry Land Agronomy, Mekelle University, ETHIOPIA
}

\begin{abstract}
One season experiment conducted at two sites in northern Ethiopia (Maychew and Mekelle). The objective of the research was to evaluate the effect of in-situ rainwater conservation and sowing-date on soil-water status, barley yield and infestation of weeds. The treatments include three alternative sowing-dates (ESD; NSD; and LSD) and two in-situ rainwater conservation measures (tie-ridge and soil-bund, replicated three times. Analysis of variance (ANOVA) was applied to evaluate the effect of the treatments on total biomass and rainwater use efficiency (RWUE) of the local barley. The average soil-water content in the upper $0.6 \mathrm{~m}$ root zone in the soil-bund and tie-ridge improved over the control treatment by $14 \%$ and $24 \%$, respectively. The grain yield on tie-ridge was increased significantly compared to the control at Maychew site. Tie-ridge improved grain yield by $4 \%$ and $18 \%$ over the control at Mekelle and Maychew, respectively. NSD significantly improved the grain yield over LSD at both experimental sites. Neither of the sowing-dates nor the in-situ rainwater conservation measures had significantly increased the dry-matter of a barley crop. However, when NSD combined with tie-ridge, the grain yield was significantly improved compared to the LSD. There was no significant difference in weed infestation in both experimental sites due to applying insitu rainwater conservation. But, numbers of weeds were significantly higher in ESD compared to NSD and LSD on both experimental sites. For this reason, NSD with tie-ridging technique can be used as an option to obtain higher barley grain yield.
\end{abstract}

Keywords: Sowing-date, In-situ conservation, Barley, Soil moisture content, Yield, Weed

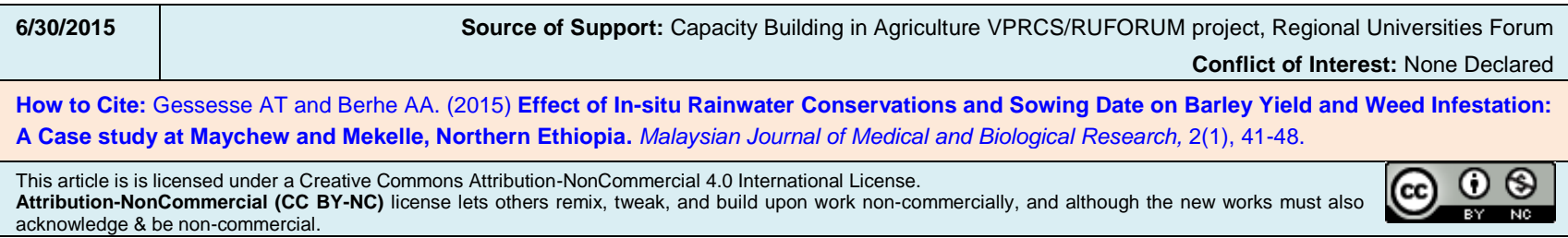

\section{INTRODUCTION}

Agriculture is the backbone of the Ethiopian economy. It is responsible for approximately $54 \%$ of the GDP, $90 \%$ of foreign exchange earnings, and $80 \%$ of the livelihoods of the population (NBP, 2008). Barley is the major staple food crop in the northern Ethiopia. It is well adapted to the altitude ranges from 1800-3000 meter above sea level (Araya and Stroosnijder, 2010).The crop is used for preparing local food types like "Enjera, Tela, Genfo, Kita, Kolo", and making Beer. Its straw is used for animal feed. Despite the importance of the crop for human and livestock use, its yield has been severely limited mainly by water shortage. Soil moisture is one of limiting factor for crop production in the semi-arid environments of Africa (Barron et al., 2003; Araya et al.; 2010a). In northern Ethiopia, particularly the small-holder farmers have faced many challenges especially the lack of secured rainwater for rain-fed agriculture. In addition to the unsecured and uneven distribution of the rainfall within the rainy season, the onset and cessation of rain varies from year to year. This variation has generated irregularities in date of sowing that has a direct impact on the length of growing period and crop production. In northern Ethiopia regardless of its severe drought risks, technologies that effectively use rainwater are limited. In addition, to what extent the climatic stress that resulted from climate change could be reduced by improving rainwater use efficiency is not known. For this reason, understanding rainfall and other associated factors that affect soil moisture variability during the crop growing period is crucial. Sowing-date technique is used to optimize the rainwater use in the growing season (Tesfay and Walker, 2004).Knowledge of the most optimal sowing-date will enable to improve rainwater use and reduce false start risk and to obtain better crop yield (Sternetal.,1981; Sivakumaretal.,1992; Reas et al., 2004; Mugalava et al., 2008). However, most farmers in northern Ethiopia are interested to sow barley on dry-soil (after few showers of rain) 
for the following reasons: to prolong the growing period of the crop, to reduce work burden and to rent their oxen and labor power. Late sowing is practiced in the absence of oxen and labor and/or due to late start of the rain. Hence, identifying the best sowing-date for barley in the growing period could have paramount importance in reducing crop failure. However, information on optimal sowing-date in the northern Ethiopia is not available. In-situ rainwater conservation measures can enhance the water availability in the crop root in order to improve the yield and water use efficiency of barley during below average rainfall condition (Araya and Stroosnijder, 2010). However, some farmers in northern Ethiopia indicated that in-situ rainwater conservation structures enhance the dominance of weed over their crops and increase the possibility of weed infestation. Report on the effect of in-situ water conservation on prevalence of weeds however is not available. Therefore, there is need to assess the effect of in-situ conservation measures on the extent of infestation of weeds. In addition, the interaction effect of in-situ rainwater conservation practices and sowing-date on grain yield has not been fully understood. In this study, an attempt was made to evaluate the effect of sowing-dates and in-situ water conservation techniques in reducing vulnerability of a barley crop to soil moisture shortage and weed infestation by its: a) soil moisture status, b) total biomass yield of barley and, c) weed occurrence.

\section{Material AND Methodology}

\section{Description of the Study Area}

The study areas are located at Maychew and Mekelle found in the northern part of Ethiopia, at $13^{\circ} 3^{\prime} \mathrm{N}$ and $12^{\circ} 47^{\prime} \mathrm{N}$ latitude and $39^{\circ} 6^{\prime} \mathrm{E}$ and $39^{\circ} 32^{\prime} \mathrm{E}$ longitude with an elevation of 2210 and 2400 meter above sea level, respectively. The climate of the study areas is tepid semi-arid with mean annual rainfall of about $600 \mathrm{~mm}$ for Mekelle site (Araya et al., $2010 \mathrm{~b}$ ) and $600-800 \mathrm{~mm}$ for Maychew site. The average minimum and maximum seasonal temperature values are $9^{\circ} \mathrm{C}$ and $22^{\circ} \mathrm{C}$ for Maychew and $9^{\circ} \mathrm{C}$ and $28^{\circ} \mathrm{C}$ for Mekelle, respectively. The soils type at Mekelle and Maychew were Cambisols and Vertisols, and the corresponding textural classes of the surface soils (top $0.2 \mathrm{~m}$ ) were silt-loam and clayloam, respectively. The soil depth for both sites, approximately $1 \mathrm{~m}$.

\section{Experimental Design and Crop Management}

The sowing-dates were adopted from the farmers practice and from the analysis based on the long-term climate data (Araya et al., 2010b). Early sowing-date (ESD) is the period corresponds to July 1-8. Normal sowing-date (NSD) occurs in period July 9-19. Whereas late sowing-date (LSD) is corresponds to the period July $19-27$. The tie-ridges were $0.15 \mathrm{~m}$ high and $0.25 \mathrm{~m}$ wide and spaced at $0.8-1.0 \mathrm{~m}$ apart and ridges were tied at intervals of $2.0 \mathrm{~m}$, and $0.1-0.12 \mathrm{~m}$ high. The practice was similar to the introduced oxen drawn rigger presented in Temesgen (2000) and McHugh et al., (2007). The soil-bunds were basin like structures with a height of $0.15-0.20 \mathrm{~m}$ soil. The conventional (control) plots were without soil and water conservation structures but with all other management practices similar to those of the in-situ water conservation treatments. The experimental design was RCBD with three replications. The plots areas were 6mby6mwith1.0mand $2.0 \mathrm{~m}$ spacing between plots and blocks, respectively.

The amount of seed and fertilizer applied was following that of the regional Bureau of Agriculture recommendations. 120 $\mathrm{kg} \mathrm{ha}^{-1}$ of barley and $100 \mathrm{~kg} \mathrm{ha}^{-1}$ of DAP and UREA were applied by broadcasting. The nitrogen fertilizer was applied half at sowing and the other half four weeks after sowing. Weed count was carried out in $1 \mathrm{~m}^{2}$ quadrant in each plot 28 days after sowing and average number of weeds per treatment was computed and weeds were removed, and the total biomass were harvested from the central $4 \mathrm{~m}^{2}$ areas of plot and dry out by sunlight. The dry grain yield and above-ground drymatter at harvest were used to evaluate the impact of different in-situ rainwater and sowing-date practices.

\section{Soil Moisture Analysis}

The soil moisture was measured using Time Domain Reflectometery (TDR) and gravimetric methods in both experimental sites. The glass fiber access tubes were installed in each plot and the data were taken using TDR at an interval of $0.2 \mathrm{~m}$ to a depth of $0.6 \mathrm{~cm}$ of the rooting depth of the barley. The soil moisture analysis was made based on the average of the observed TDR (soil moisture in vol. \% or m $\mathrm{m}^{3} \mathrm{~m}^{-3}$ ) and gravimetric value $\left(\mathrm{kg} \mathrm{kg}^{-1}\right)$ of soil moisture of each treatment. Based on Eq.1 the gravimetric soil moisture $\left(\mathrm{kg} \mathrm{kg}^{-1}\right)$ converted to its corresponding volumetric value by multiplying its bulk density (Wiyo et al., 2000) and the soil moisture obtained in volumetric water content $\left(\mathrm{m}^{3} \mathrm{~m}^{-3}\right)$ were converted into equivalent depth per unit soil depth $(\mathrm{mm})$ by multiplying $1000 \mathrm{kgm}^{-3}$ of density of soil moisture content and its soil moisture depth (Raes, 2001).

Soilwatercontent $=\left(\frac{\text { Bulk density }}{\text { Density of soil watr solution }}\right)$ mass of water content $\quad$.Eq.1

Threshold soil moisture $(\mathrm{mm})$ of the remaining soil moisture amount after the Readily Available Moisture RAM $(\mathrm{mm})$ is depleted (where depletion factor of barley (p) is 0.55), and computed using Eq.2.

Threshold $(\mathrm{mm})=(1-\mathrm{p}) \times \mathrm{RAM}+\mathrm{PWP} \quad \ldots \ldots \ldots \ldots \ldots \ldots \ldots \ldots . . . \mathrm{Eq} .2$ 
The rainwater use efficiency (RWUE in $\mathrm{kg} \mathrm{ha}^{-1} \mathrm{~mm}^{-1}$ ) and harvest index (HI) of different crops can be determined using Eq.3 and Eq.4, respectively (Araya and Stroosnijder, 2010).

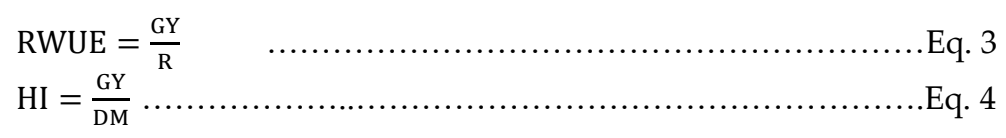

\section{Data Analysis}

SAS statistical software package was used to compute the effect of treatments, on grain yield, dry-matter (DM), harvesting index and rainwater use efficiency of the local barley and on weed infestation. Mean separation of significant difference was done by Duncan Multiple range.

\section{Results and Discussion}

\section{Soil Moisture Status}

Water plays important role for crop growth in realizing i) photosynthesis ii) Translocation of plant synthesis from leaf to other part of the plant, and iii) Transportation of mineral nutrients. Thus, the presence of adequate water in the root zone improves the aforementioned roles of water. Effective in-situ conservation measures capture rainwater in the soil during rainy periods for continued plant uptake during moisture sensitive crop growth stage.

The average soil moisture content within the barley root zone at Maychew sites for each sowing date treatments and in-situ rainwater conservation measures are shown in Fig.1. The available soil moisture content values at FC and at PWP were 214 and $124 \mathrm{~mm}$, respectively. The total available moisture (TAM) content was 90mm and the readily available moisture (RAM) content was estimated to be $49.5 \mathrm{~mm}$. Moisture stress began when it reaches below threshold $(164.5 \mathrm{~mm})$ as indicated by the threshold line in Fig.1.

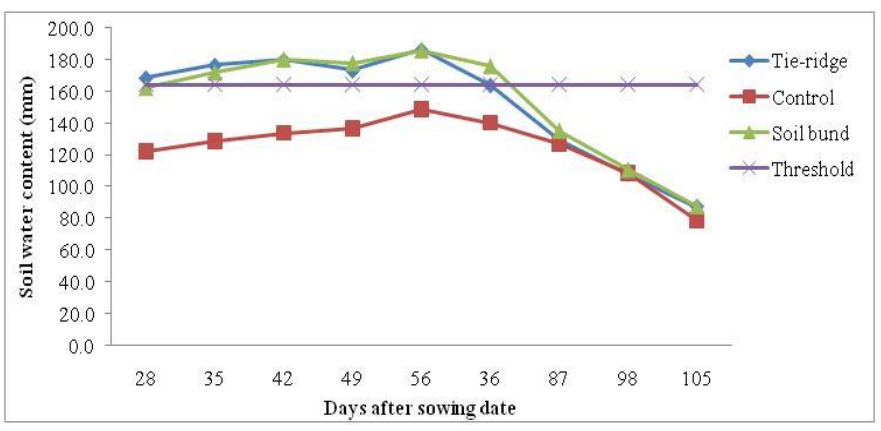

Fig.1: Average soil moisture content at Maychew sites.

Similarly, at Mekelle site, the available soil moisture content values at FC and PWP were 244mm and 102mm, respectively. The total available moisture (TAM) content was142mm and the readily available moisture (RAM) content was $78 \mathrm{~mm}$. Moisture stress began when it reached below threshold $(166 \mathrm{~mm})$ as indicated by threshold line in Fig.2.

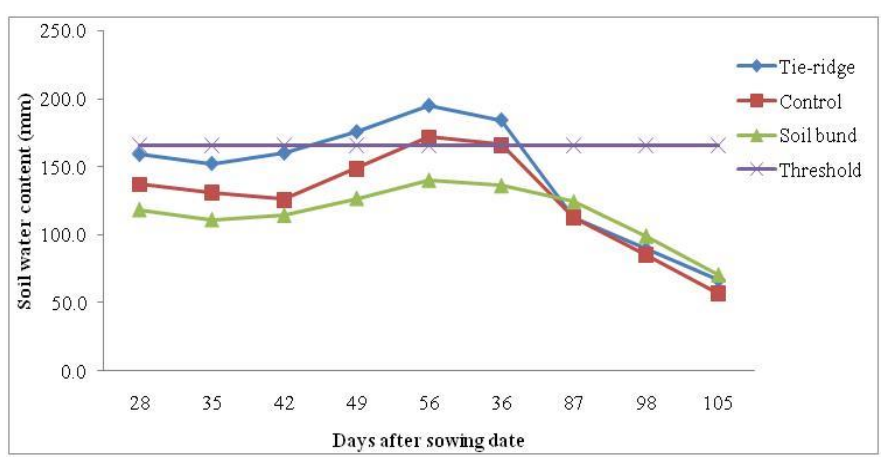

Fig.2: Average soil moisture content at Mekelle sites.

As shown in Fig.1, the soil moisture content per unit soil depth for both tie-ridge and soil bunds were $23 \%$ higher than that of the control. Similarly, as shown in Fig.2, tied ridge improved the soil moisture in the root zone by $14 \%$ compared to the control. McHugh et al., (2007) found tied ridge improved the soil moisture storage by $9 \%$ - $24 \%$ compared to the control. Also, Araya and Stroosnijder (2010) obtained 13\% - 27\% increment in soil moisture content with tie-ridge compared to the control. Many authors reported that tie-ridge enhances positive partitioning of rainwater for better utilization of the soil moisture in the root zone (McHugh et al., 2007; Nuti et al., 2009; Temesgen et al., 2009). Although, tie-ridge increased the soil moisture in the root zone, there was no significant difference in soil 
moisture availability between tie-ridge and soil bund at both sites. Furthermore, in spite of the more available water in the tie-ridge, there was small difference in lengthening (prolonging) the moisture availability period in the season (Fig.1 and Fig.2). Araya and Stroosnijder (2010) recommended tied ridge for below average rainfall season. In below average rainfall seasons, barley grown without soil water conservation is likely to be exposed to late water stress earlier than barley grown with in-situ conservation measures.

\section{Effect of In-Situ Rainwater Conservation Practices}

The tie-ridge improved the GY and RWUE significantly $(\mathrm{p}=0.05)$ over the conventional at Maychew and no significant difference, however, was found on dry-matter (DM) and $\mathrm{HI}$ although it tends to show that relative increments in DM and $\mathrm{HI}$ due to in-situ conservation measures compared to the control (table1). Whereas at Mekelle site, none of the insitu rainwater conservation measures had significant difference on GY, DM, HI and RWUE as compared to the control. There was a relative increment on GY, HI and RWUE with tie-ridge as compared to the control at Mekelle (Table1)

Table1: Effect of in-situ rainwater conservation practices on barley yield and yield parameters at Maychew and Mekelle sites

\begin{tabular}{|l|l|l|l|l|l|l|l|l|}
\hline \multirow{2}{*}{ Treatments } & \multicolumn{4}{|c|}{ Maychew } & \multicolumn{4}{c|}{ Mekelle } \\
\cline { 2 - 9 } & GY & DM & HI & RWUE & GY & DM & HI & RWUE \\
\hline Tie-ridge & $2181 \mathrm{a}$ & $7678 \mathrm{a}$ & $28.6 \mathrm{a}$ & $3.76 \mathrm{a}$ & $1535 \mathrm{a}$ & $6882 \mathrm{a}$ & $22.1 \mathrm{a}$ & $2.67 \mathrm{a}$ \\
\hline Soil-bund & $2044 \mathrm{ab}$ & $7742 \mathrm{a}$ & $26.5 \mathrm{a}$ & $3.52 \mathrm{ab}$ & $1459 \mathrm{a}$ & $6598 \mathrm{a}$ & $21.9 \mathrm{a}$ & $2.54 \mathrm{a}$ \\
\hline Control & $1848 \mathrm{~b}$ & $6997 \mathrm{a}$ & $26.3 \mathrm{a}$ & $3.19 \mathrm{~b}$ & $1474 \mathrm{a}$ & $6921 \mathrm{a}$ & $21.4 \mathrm{a}$ & $2.57 \mathrm{a}$ \\
\hline $\mathrm{P}=0.05$ & $* *$ & $\mathrm{~ns}$ & $\mathrm{~ns}$ & $* *$ & $\mathrm{~ns}$ & ns & ns & ns \\
\hline
\end{tabular}

**Significant at 0.05; ns, non-significant; where; GY: (kg ha-1); DM: (kg ha-1); HI: (\%); and RWUE: $\left(\mathrm{kg} \mathrm{ha}^{-1} \mathrm{~mm}^{-1}\right)$; Different letters in a column showed significant difference.

At Maychew there was 18\% increase in GY with tie-ridge over the control. Soil bund was a 10\% increase in GY compared to the control. At Mekelle site tie-ridge improved the GY by $4 \%$ over the control whereas the GY obtained in the soil bund was lower than the control. The reason was not fully understood, but it could be due to excess rainwater during sensitive stage as barley is sensitive to aeration stress (Araya et al., 2010b). The potential water requirement of a barley crop varied from 340 to $375 \mathrm{~mm}$ (Araya et al., 2011). However, the study site received rainfall $580 \mathrm{~mm}$ for a short period (mid-July to mid-August), and hence, the crop with treatment soil bund might have suffered aeration stress due to water logging.

According to Mc Hugh (2007), tied ridge improved the grain yield by $73 \%$ in a sorghum field. Araya and Stroosnijder (2010) also reported that tie-ridging improved the grain yield by $60 \%$ in a barley field. As shown in Table1, tie-ridge and soil bund improved the dry-matter by $10 \%$ compared to the control at Maychew. However, lower dry-matter was found at Mekelle site in tie-ridge and soil bund as compared to control. In-situ rainwater conservation may not significantly improve the dry-matter during above average rainfall at barley sensitive stage (Araya et al., 2010b). However, in-situ rainwater conservation measures have benefits such as reducing runoff, increasing groundwater recharge, and improving the nutrient status (Nuti et al., 2009).

Slightly higher HI were observed with tie- ridge treatment and followed by soil bund. Araya and Stroosnijder (2010a) reported that harvest index was slightly higher in treatment with tie-ridge compared to the control treatment. At Maychew site, tie-ridge showed significantly $(\mathrm{p}=0.05)$ higher RWUE $\left(3.76 \mathrm{~kg} \mathrm{ha}^{-1} \mathrm{~mm}^{-1}\right)$ compared to the control $(3.19 \mathrm{~kg}$ ha${ }^{1} \mathrm{~mm}^{-1}$ ) (Table 1). The result indicated that in-situ rainwater conservation measures especially tie-ridge was effective in conserving rainwater. Tie-ridge reduced not only runoff, but also reduces soil and nutrient loss and improves water availability in the root zone for the crop growth as compared to the control. McHugh et al. (2007) concluded that conservation tillage can be beneficial for improving soil moisture and reducing runoff and soil loss. Overall, tie-ridge was most effective at improving rainfall partitioning (i.e. less runoff from field) for dry spell mitigation.

\section{Effect of Sowing Date}

Sowing-date techniques is known to optimize the crop RWUE and allow fit the majority of sensitive crop growth period with the peak rainy season (Tesfay and Walker, 2004). At Maychew experimental site, ESD (July04) and NSD (July12) showed significantly high difference over the LSD (July 22) ( $\mathrm{P=0.05}$ ) in GY, HI, and RWUE. NSD significantly improved the GY, H.I and RWUE over ESD at Mekelle. Although, there was no significant difference ( $\mathrm{p}=0.05)$ in drymatter (DM) due to sowing date at both experimental sites. However, there was relative increment in DM with NSD when compared to LSD and ESD at Maychew (Table2). 
Table2: Effectofsowing date on barley yield and yield parameters at Maychew and Mekelle

\begin{tabular}{|c|c|c|c|c|c|c|c|c|}
\hline \multirow{2}{*}{ Treatment } & \multicolumn{4}{|c|}{ Maychew } & \multicolumn{5}{c|}{ Mekelle } \\
\cline { 2 - 9 } & GY & DM & HI & RWUE & GY & DM & HI & RWUE \\
\hline ESD & $2180 \mathrm{a}$ & $7167 \mathrm{a}$ & $30.5 \mathrm{a}$ & $3.37 \mathrm{a}$ & $1358 \mathrm{~b}$ & $6446 \mathrm{a}$ & $20.8 \mathrm{~b}$ & $2.36 \mathrm{~b}$ \\
\hline NSD & $2296 \mathrm{a}$ & $7947 \mathrm{a}$ & $28.9 \mathrm{a}$ & $3.96 \mathrm{a}$ & $1673 \mathrm{a}$ & $6663 \mathrm{a}$ & $25.1 \mathrm{a}$ & $2.92 \mathrm{a}$ \\
\hline LSD & $1596 \mathrm{~b}$ & $7303 \mathrm{a}$ & $22.1 \mathrm{~b}$ & $2.75 \mathrm{~b}$ & $1437 \mathrm{ab}$ & $7293 \mathrm{a}$ & $19.6 \mathrm{~b}$ & $2.5 \mathrm{ab}$ \\
\hline $\mathrm{P}=0.05$ & $* *$ & $\mathrm{~ns}$ & $* *$ & $* *$ & $* *$ & $\mathrm{~ns}$ & $* *$ & $* *$ \\
\hline
\end{tabular}

**Significant at0.05; ns, non-significant; Different letters in a column showed significant difference

NSD increased the GYby44\%and13\% over LSD at Maychew and Mekelle, respectively (table2). ESD increased the GY over LSD by 37\% at Maychew site (table2).The increment in GY was due to better use of rainwater by the crop during the growing season. Unlike NSD and ESD, LSD exposed to later seasonal drought because the late season sowing received short rainy period compared to ESD and NSD. Knowledge of optimal growing season is very important to set the type of crop to be cultivated and in planning of sowing (Mugalavai et al., 2008). Crops sown early have got the greater opportunity for receiving grain water for an extended period than that of the late sowing. NSD improved the H.I by $28 \%$ and $31 \%$ over LSD at Mekelle and Maychew, respectively (table2). The result showed that, sowing-date optimizes RWUE (table2). The NSD improved the RWUE by $44 \%$ and $16 \%$ over LSD and ESD at Maychew. Similarly, NSD improved the RWUE by $17 \%$ and $23 \%$ over LSD and ESD at Mekelle, respectively (table2). This indicates that NSD escapes from early and late season dry-spells and hence, minimizes crop failure.

\section{Interaction Effect of In-Situ Rainwater Conservation and Sowing Date}

The combined treatment effect of sowing-date and in-situ rainwater conservation practices on a barley fields were significantly different $(\mathrm{p}=0.05)$ in GY, HI, and RWUE at Maychew experimental site. However, at Mekelle experimental site structural significance difference in GY, HI, and RWUE was not observed (table3).

Table3: Interaction effect of in-situ RWC and sowing-date on yield and yield parameters

\begin{tabular}{|c|c|c|c|c|c|c|c|c|}
\hline \multirow{2}{*}{$\begin{array}{c}\text { Interaction } \\
\text { Effect }\end{array}$} & \multicolumn{4}{|c|}{ Maychew } & \multicolumn{4}{|c|}{ Mekelle } \\
\hline & GY & $\mathrm{DM}$ & H.I & RWUE & GY & $\mathrm{DM}$ & H.I & RWUE \\
\hline $\mathrm{ESD}^{*} \mathrm{Tr}$ & $2232.5 \mathrm{ab}$ & 7358.3ab & $30.6 a$ & $3.85 \mathrm{ab}$ & $1540.0 \mathrm{abc}$ & 7264.2ab & 20.7bcd & $2.68 \mathrm{abc}$ \\
\hline $\mathrm{ESD}^{*} \mathrm{Sb}$ & $2336.7 \mathrm{ab}$ & 7333.3ab & $31.9 \mathrm{a}$ & $4.03 \mathrm{ab}$ & $1069.2 \mathrm{c}$ & $5560.8 b$ & $19.3 \mathrm{~cd}$ & $1.86 \mathrm{c}$ \\
\hline $\mathrm{ESD}^{*} \mathrm{C}$ & 1971.7bcd & 6808.3ab & 28.9ab & $3.4 \mathrm{bcd}$ & $1464.2 \mathrm{abc}$ & 6513.3ab & $22.3 \mathrm{bcd}$ & $2.55 \mathrm{abc}$ \\
\hline NSD*Tr & $2585.2 \mathrm{a}$ & 8183.3a & $31.7 \mathrm{a}$ & $4.46 \mathrm{a}$ & 1828.3a & $6564.2 \mathrm{ab}$ & $27.7 \mathrm{a}$ & $3.18 \mathrm{a}$ \\
\hline $\mathrm{NSD}^{*} \mathrm{Sb}$ & 2216.7ab & 7958.3ab & $27.8 \mathrm{ab}$ & $3.82 \mathrm{ab}$ & $1614.2 \mathrm{ab}$ & $6360.0 \mathrm{ab}$ & $25 \mathrm{ab}$ & $2.81 \mathrm{ab}$ \\
\hline $\mathrm{NSD}^{*} \mathrm{C}$ & $2088.3 b c$ & $7700 \mathrm{ab}$ & 27.1ab & $3.6 \mathrm{bc}$ & $1576.7 \mathrm{abc}$ & 7064.2ab & $22.7 b c$ & $2.75 a b c$ \\
\hline $\mathrm{LSD}^{*} \mathrm{Tr}$ & $1725.0 \mathrm{cde}$ & 7491.7ab & $23.6 b c$ & 2.97cde & $1236.7 \mathrm{bc}$ & 6818.3ab & $18 \mathrm{~d}$ & $2.15 b c$ \\
\hline $\mathrm{LSD}^{*} \mathrm{Sb}$ & $1579.2 \mathrm{de}$ & 7933.3ab & $19.7 \mathrm{c}$ & $2.27 \mathrm{de}$ & $1692.5 \mathrm{ab}$ & $7872.5 a$ & $21.3 \mathrm{bcd}$ & $2.95 \mathrm{ab}$ \\
\hline $\mathrm{LSD}^{*} \mathrm{C}$ & $1485 \mathrm{e}$ & $6483.3 b$ & $22.9 \mathrm{bc}$ & $2.56 \mathrm{e}$ & $1380.8 \mathrm{abc}$ & 7186.7ab & $19.3 \mathrm{~cd}$ & 2.40abc \\
\hline SD* SWC & $* *$ & ns & $* *$ & $* *$ & ns & ns & ns & ns \\
\hline
\end{tabular}

**Significant at 0.05; ns, non-s ignificant; Tr: tie-ridge; Sb: soil-bund and C: control; SWC: soil water conservation, SD: sowing-date; Different letters in a column showed significant difference.

At Maychew, when tie-ridge combined with NSD improved the GY significantly compared to the tied-ridge combined with LSD. Grain yield increment was observed when tie-ridge combined with NSD by $48 \%-50 \%$ and $16 \%-20 \%$ than tie-ridge combined with LSD, and ESD, respectively (table3). However, there was no significant difference in DM at both experimental sites. The result implies that if farmers practiced NSD in combination with tie-ridging they could obtain better quantity of GY. Soil bund improved the GY by $48 \%$ when they combined with ESD and by $40 \%$ when they combined with NSD at Maychew experimental site (table3). The DM was improved at LSD when combined with in-situ rainwater conservation measures as compared to ESD and NSD at both experimental sites. However, the reason for the increment was not clearly understood. Araya et al. (2010b) also found higher Teff biomass from a mild water stressed crop than the fully irrigated crop. ESD, when combined with tie-ridge and soil bund, resulted in significantly higher HI when compared to LSD and NSD at Maychew site. However, at Mekelle site, only NSD combined with tieridging improved the H.I significantly ( $\mathrm{p}=0.05$ ) compared to ESD and LSD (table 3). Generally, NSD improved the HI by $34 \%$ and $54 \%$ when combined with tie-ridge over LSD and by $4 \%$ and $34 \%$ over ESD at Maychew and Mekelle experimental sites respectively. In both experimental sites the NSD, when combined with tie-ridge treatments, improved the RWUE significantly ( $\mathrm{p}=0.05$ ) over LSD (table3). The NSD when combined with tie-ridge improved RWUE by $16 \%-18 \%$ and $48 \%-50 \%$ than combined with tie-ridge ESD and LSD respectively. NSD, RWUE was increased by $5 \%$ and $57 \%$ in Mekelle site and $18 \%$ and $4 \%$ in Maychew site, compared to LSD and ESD when combined with in- 
situ conservation respectively. The result, demonstrates that farmers can optimize the rainwater by constructing tieridge and sow their crop during NSD to reduce water stress and crop failure.

\section{Single effect of in-situ rainwater conservation practice and sowing-date on weed infestation}

There was no significant difference in weed infestation due to in-situ soil water conservation practices in a barley fields at both sites (table4). However, weeds were more prevalent and significantly higher with ESD at Maychew and Mekelle experimental sites.

Table4: Effect of in-situ SWC and sowing date on weed infestations

\begin{tabular}{|c|c|c|c|}
\hline Treatment & level & \multicolumn{2}{|c|}{ Number of weeds } \\
\cline { 2 - 4 } & & Maychew & Mekelle \\
\hline \multirow{4}{*}{$\begin{array}{c}\text { In-situ } \\
\text { SWC practice }\end{array}$} & Tie-ridge & $80 \mathrm{a}$ & $187 \mathrm{a}$ \\
\cline { 2 - 4 } & Soil bund & $79 \mathrm{a}$ & $160 \mathrm{a}$ \\
\cline { 2 - 4 } & Control & $78 \mathrm{a}$ & $180 \mathrm{a}$ \\
\cline { 2 - 4 } & $\mathrm{p}=0.05$ & $\mathrm{~ns}$ & $\mathrm{~ns}$ \\
\hline \multirow{3}{*}{ Sowing Date } & $\mathrm{ESD}$ & $94 \mathrm{a}$ & $214 \mathrm{a}$ \\
\cline { 2 - 4 } & $\mathrm{NSD}$ & $75 \mathrm{~b}$ & $169 \mathrm{ab}$ \\
\cline { 2 - 4 } & $\mathrm{LSD}$ & $67 \mathrm{~b}$ & $142 \mathrm{~b}$ \\
\cline { 2 - 4 } & $\mathrm{p}=0.05$ & $* *$ & $* *$ \\
\hline
\end{tabular}

**Significant at0.05; ns: non-significant; Different letters in a column showed significant difference

The result disproves the negative perception of some farmers that weed infestation increase in fields with in-situ conservation measures. For this reason, a practicing in-situ rainwater conservation measure on cropped land does not enhance weed prevalence. However, the number of weeds in ESD was significantly higher from NSD and LSD. As shown in (table 4), ESD increased weed infestation by $25 \%$ and 40 to $50 \%$ over NSD and LSD at both sites, respectively. The result indicated that, the numbers of weeds in NSD and LSD minimized because more weeds were observed by the first rains and were killed by plowing during NSD and LSD. Barley sown on dry soils (ESD) has the chance to germinate with weeds just after few showers of rain are received. Hence, more weed infestation is likely to occur in ESD. Prevalence of weed may also have cost implications in weeding and may also significantly affect the crop yield due to weed competition.

\section{Combined effect of In-situ RWC and sowing-date on weed infestation}

There was no significant difference due to the combination of sowing date and in-situ rainwater conservation treatment at both sites. Generally, the result investigated that, ESD when combined with both in-situ water conservation measures, increased the number of weeds by $10 \%-17 \%$ and $34 \%-56 \%$ over NSD and LSD respectively. From a weed infestation point of view, practicing of ESD is not advisable unlike the case of NSD and LSD (table5).

Table5. Combined effects of In-situ SWC and sowing-date on weed infestation

\begin{tabular}{|c|l|c|c|c|c|}
\hline \multirow{2}{*}{$\begin{array}{c}\text { Experimental } \\
\text { Site }\end{array}$} & In-situ & \multicolumn{3}{|c|}{ Sowing Dates } & \multirow{2}{*}{$\mathrm{p}=0.05$} \\
\cline { 2 - 6 } & RWC & ESD & NSD & LSD & \\
\hline \multirow{4}{*}{ Maychew } & Tie-ridge & $78 \mathrm{ab}$ & $88 \mathrm{ab}$ & $72 \mathrm{bc}$ & $\mathrm{ns}$ \\
\cline { 2 - 6 } & Soil-bund & $104 \mathrm{a}$ & $68 \mathrm{c}$ & $64 \mathrm{c}$ & $* *$ \\
\cline { 2 - 6 } & Control & $99 \mathrm{ab}$ & $69 \mathrm{bc}$ & $65 \mathrm{c}$ & $* *$ \\
\cline { 2 - 6 } & $\mathrm{P}=0.05$ & $\mathrm{~ns}$ & $* *$ & $\mathrm{~ns}$ & \\
\hline \multirow{4}{*}{ Mekelle } & Tie-ridge & $222 \mathrm{ab}$ & $187 \mathrm{abc}$ & $150 \mathrm{abc}$ & $\mathrm{ns}$ \\
\cline { 2 - 6 } & Soil-bund & $184 \mathrm{abc}$ & $183 \mathrm{abc}$ & $110 \mathrm{c}$ & $\mathrm{ns}$ \\
\cline { 2 - 6 } & Control & $236 \mathrm{a}$ & $137 \mathrm{bc}$ & $166 \mathrm{bc}$ & $* *$ \\
\cline { 2 - 6 } & $\mathrm{P}=0.05$ & $\mathrm{~ns}$ & $\mathrm{~ns}$ & $\mathrm{~ns}$ & \\
\hline
\end{tabular}

**Significant at $\mathrm{p}=0.05$; ns: non-significant; Different letters in a column and row showed significant difference.

\section{CONCLUSION}

Barley growth and development are affected by water stress. To avoid the effect of dry-spell on the barley growth and development, alternative water management practices are important towards better use of rainwater in semi-arid areas. Tie-ridge captured rainwater and improved soil moisture in the root zone and reduced loss of water due to runoff consequently increased the GY compared to the conventional practice. The use of tie-ridge improves RWUE while, the increment in GY and RWUE in the case of soil bund was insignificant. Optimal sowing date was found to be one of the methods to maximize the RWUE in a barley field. Thus, NSD gave higher GY and RWUE compared to LSD. 
However, there was no significant difference in DM due to the different sowing dates. NSD has enabled barley to better use of rainwater during the season. Unlike NSD, LSD shortened the growing season and exposed the crop to latter season drought. In addition, the GY and RWUE significantly increased when tie-ridge combined with NSD. There was no significant difference in the number of weeds due to implementation of in-situ rainwater conservation practices. Hence, an assumption of some farmers that states weed infestation increased in farm lands with in-situ water conservation was disproved. Rather sowing-dates significantly affected the infestation by weeds. Weed infestation was found to be significantly higher in ESD.

\section{RECOMMENDATION}

In-situ water conservation measures recommended capturing the rainwater to mitigate dry-spells and to obtain higher GY and DM. However, it may not be recommended in barley in times of above average rainfall. In-situ water conservation practices need to be encouraged. However, additional assessment in various areas across different seasons and financial feasibility on weed prevalence is required. A farmer practicing NSD alone or combined with tieridge would be expected to obtain higher GY (food) for his family and DM for fodder. Delayed sowing-date (LSD) and ESD were proved to expose the crop to late season drought and enhanced weed infestation respectively.

\section{ACKNOWLEDGEMENT}

I would like to express sincere appreciation to the Regional Universities Forum for Capacity Building in Agriculture VPRCS/RUFORUM/ project for funding the research and Mekelle University College of Dry-land Agriculture and Natural Resources for supporting most of the research materials and equipment to under-take the research.

\section{REFERENCES}

Alam MM, Quevauviller P. An Evaluation of Integrated Water Resources Management (IWRM) activities in Bangladesh. Asia Pacific Journal of Energy and Environment. 2014;1(1):22-38.

Araya, A., and Stroosnijder, L., 2010. Effect of tied-ridges and much on barley (Hordeum Vulgare) rainwater use efficiency and production in northern Ethiopia. Agricultural water management: 97. 841-847.

Araya, A., Keesstra, S.D. and Stroosnijder, L., 2010b. A new agro-climatic classification for crop suitability zoning in northern semi-arid Ethiopia. Agric. Forest Meteorology: 10.1016/ J.agroformet. 2010.04.003

Araya, A., Solomon Habtu, Mitiku Haile, F. Sisay and Tadesse Dejene 2011. Determination of local barley (Hordeum vulgare) crop coefficient and comparative assessment of water productivity for crops grown under the present pond water in Tigray, Northern Ethiopia. Momena J. Sci.in press.

Araya, A., Solomon H., Kiros, M.H., Afewerk, K., Tadesse, D., 2010a. Test of Aqua-Crop model in simulating biomass and yield of water deficient and irrigated barley (hordeum vulgare). Agricultural Water Management. 97, 1838-1846.

Barron, J., Rockstrom, J., Gichuki, F., Hatibu, N., 2003. Dry-spell analysis and maize yield for semi-arid locations in east Africa. Agriculture and Forest Metrology 117, 23-37.

El-Wakil, A., El-Maaty, W., \& Awad, F. (2014). Studies on Biosorption of Mercury (II) from Aqueous Solution on Nitric Acid Modified Activated Carbon Prepared from Water Hyacinth. ABC Journal Of Advanced Research, 3(1), 51-71. Retrieved from http://journals.abc.us.org/index.php/abcjar/article/view/5.7

Ilahi, H., Saadaoui, I., Bryant, C., \& Rejeb, H. (2014). Anthropized Agrarian Landscape in the Central-west of Tunisia: Attempts to Evaluate the Production's Systems of Apples-trees Orchards in the Delegation of Sbiba. ABC Journal Of Advanced Research, 3(1), 34-43. Retrieved from http://journals.abc.us.org/index.php/abcjar/article/view/5.5

Katsaruware RD and Gwembire J. 2014. Float Trays as an Alternative to Methyl Bromide in Tobacco Production in Hurungwe District, Zimbabwe. Asian Journal of Applied Science and Engineering, 1, 119-128.

McHugh, O.V., Steenhuise, T.S., Berihun Abebe, Fernandes, E.C.M., 2007. Performance of in-situ rainwater conservation tillage techniques on dry-spell mitigation and erosion control in the drought-prone north wello zone of the Ethiopia highlands. Soil and tillage research $97.19-36$

Mugalavai, E.M., Emmanuel C. Kipkoror, E.C., Reas, D., and Rao, M.S., 2008. Analysis of rainfall onset, cessation and length of growing season for western Kenya. Agric. Forest Meteorol.148, 1123-1135.

Nahar K. 2012. Biogas Production from Water Hyacinth (Eichhornia Crassipes). Asian Journal of Applied Science and Engineering, 1, 9-13.

National Biogas Program, 2008. Program Implementation Document on Biogas for Better Life. Published by: Ethiopian Rural Energy Development and Promotion Center (EREDPC). 
